\title{
Teaching Portuguese Language in the Early Years of Elementary School: an Analysis of Pedagogical Practice in a School in Goiás, Brazil
}

\author{
Zenaide Dias Teixeira \\ Professor Doctor \\ Department of Pedagogy \\ Universidade Estadual de Goiás (UEG) \\ Brazil \\ Kleber Aparecido da Silva \\ Professor Doctor \\ Postgraduate Program in Linguistics (PPGL) \\ Universidade de Brasilia (UnB) \\ Brazil \\ Marcelo Duarte Porto \\ Professor Doctor \\ Department of the Master's Degree in Science Teaching \\ Universidade Estadual de Goiás (UEG) \\ Brazil
}

\begin{abstract}
This article discusses the teaching of Portuguese in the early years of Elementary School. Our objective was to analyze pedagogical practices, starting from the discussion about normative grammar teaching and language teaching, from a perspective of Educational Sociolinguistics. In this sense, we did the observation of classes in a school that attends this school stage, in the municipality of Luziânia, Brazil. We use as basis the postulates of the interpretative paradigm, one of the strands of the social sciences. In this sense, we opted for qualitative research methodology. Observations of classes were carried out in three classes, being a class of $3^{\circ}$ year, one of $4^{\circ}$ and another of $5^{\circ}$ year. We chose these classes because we consider that the students are already at a more advanced stage of literacy process. Four classes were observed in each class. After analyzing the collected data, we conclude that the relationship between theory and practice in Portuguese language teaching in the initial years of elementary school education needs to be considered with more emphasis, so that the objectives of the teacher with certain activities become clearer both for him and for the students.
\end{abstract}

Keywords: Educational Sociolinguistics, Language Teaching, Portuguese Language.

\section{Introduction}

In this article, we will reflect on pedagogical practices in the teaching of Portuguese language in the first years of elementary school based on observations of classes performed at this school stage in a public school in Luziânia, located in the state of Goias in Brazil. Despite the wide discussion about language teaching, teaching Portuguese is often still confused with teaching normative grammar, however, they are different objects. Bagno (2007b), to clarify this difference, compares such objects to the river and the Igapó: "While the language is a large, long, wide river that never stops in its course, the normative grammar is only an Igapó, a large pool of still water, a puddle, a marsh, a swampy terrain”.(Bagno, 2007b, p.10).

Thus, a major problem in Portuguese language teaching is to decide how to teach it, since the individual, when starting at school, not only knows it, but also uses this "large, long river" and the teacher, in most cases, is the normative grammar, "the Igapó," which is renewed only in the flood which, in turn, is slow to come. It is not so easy, however, to know fully the cultured norm. The greatest evidence of this is the hundreds of thousands of students who finish high school in Brazil without knowing how to use it. 
There are many difficulties for primary and secondary students to apply the knowledge brought by Normative Grammar, both in decontextualized phrases and in the daily use of the language. Often, these difficulties are consequences of failures that the grammar itself brings in its definitions (Teixeira, 2010).

In addition to these faults, Silva and Koch (2003, p. 48) point to another problem, redundancy, which will also hamper the learning of cultured language: "In Portuguese, it is up to the article to mark, explicitly or implicitly, the gender of substantive names. Consequently, gender bending in names is an accessory, redundant trait. "They do not point to redundant marks only in the bending of genres, but also in number bending, since most of the words" apart from the addition of -s, ("balão - balões, ladrão - ladrões ...)" and "a small number has, in addition to -s, an alternation of the semivowel (alemão - alemães , capelão - capelães)" (Silva; Kock, 2003,p. 54).

According to Travaglia (2009, p.10), in order to start thinking about how to solve the problems surrounding Portuguese language teaching, the teacher should first outline his goal, thinking about the type of skill he intends to develop in his student . Considering the objectives of Portuguese language teaching, the author affirms that there are, fundamentally, four options: to develop the communicative competence of the users of the language; to lead the student to master the cultured norm, thus favoring the written variety; to bring the student to the knowledge of the linguistic institution in order to know its constitution and to understand how it works; and teach the student to think scientifically.

In this way, when the teacher decides what is the goal that he will adopt for teaching the Portuguese language, it is easier to decide how to work. The how to work implies a series of choices and, among them, in the choice of the type of grammar that will be adopted. Travaglia (2009) cites eleven different types of grammar, including normative grammar, descriptive grammar, and internalized grammar. The first consists of a set of rules that are prescribed. A set of laws that dictates how language users should speak and ignores how they speak. The second does not prescribe, but describes how language works. And the third is that which considers how the individual speaks without making value judgments; it considers a set of rules, but a set of internal rules with which the speakers can organize themselves to communicate and distinguish what is accepted in the language of what is not. To better illustrate these three grammars, let us make a paraphrase of Saussure's famous metaphor in relation to language, using football. Whereas, when the game is going on, there is a broadcaster and, well before, there is a commission setting the rules. Well, this commission does not go into the field, it does not go to practice, look at the game from outside and say how it should be. He judges what is best and sets the rules, which players would have to obey under penalty of being punished. This is what happens with normative grammar, it prescribes the rules, it does not consider the users and their practices, their coexistence with the language; and the speaker should simply obey, also on pain of being punished: with social exclusion.

Considering now the speaker's point of view that only tells what is happening on the field in order to inform the listener of all the bids, he only sees what is happening, narrates, tells, describes. This is what happens with descriptive grammar, which describes what happens in the language, but does not impose, does not dictate rules and can describe any variety, of any language.

In a later situation, players have the internalized rules of the game, they know that, for example, they can not catch the ball and make a goal with their hands. This is where internalized grammar comes in, for the speakers know the rules and use it unconsciously, knowing how to chain words so that they can be understood, that they can make a goal when they are in a situation of communication.

We highlight positively the first objective put by Travaglia (2009) for the teaching of the Portuguese language: to develop in the student the communicative competence; as well as the third conception of grammar mentioned in the previous paragraph; since explaining the rules, decorating so many nomenclatures does not help the individual to communicate better, much less to use the language appropriately in different situations. The speaker needs to be clear in his mind that language is an institution that we use and that, using it properly, can more easily and consciously achieve the communicability goals expected in each communicational situation.

However, it is known that the school adopts as the object of teaching, in Portuguese, the so-called "cultured norm", which is nothing more than the variant of prestige, that "variety of language that at a given moment in history, the one used by the most influential citizens of the most powerful region of the country, was chosen to serve as an expression of the power, of the culture of that group "(Possenti in Geraldi 1984, p. 50). What about the other variants? How are they? Excluded. And, in addition to working with only one of many linguistic variants, language teaching still ends up favoring metallinguistic objectives, basically meeting the last of the four goals pointed out by Travaglia (2009). 
A rather curious fact is that writers did not seek language scholars to learn the "art of good talk". On the contrary, it is the language scholars who have chosen the good writers to say how the language should work. As Dionysius of Thrace (In Lobato, 1986, 80) said in his definitions of grammar: "grammar is the practical knowledge of the general uses of poets and writers of prose"; and Varroo (idem: 81), sev. I a.C .: Grammar is "the systematic knowledge of the use of the majority of poets, historians, and orators." Lobato (1986: 82) also states that the "grammars of Donato and Prisciano were adopted in the study of classical Latin, which was the language of scholarship, teaching, diplomacy and the Church." It is even more curious to note that these authors were not based on the language spoken by the majority, but the one spoken by the minority. Guess why? Certainly because of a socio-political-economic question, since the majority, the masses, do not have status, have no political power, and so little economic.

The problem is not restricted only to what variety to teach in school, but also to how to teach; since, in most cases, the school sees this questioning as a pedagogical problem only, and also not as a social problem (Almeida in Geraldi, 1984, p. 16). It is also worth mentioning that linguistic variation also exists because of social inequalities / differences: a person who did not have the opportunity to attend school, or attended but did not have the physical or psychic conditions to enjoy, will not speak using the same who had the opportunity; an elderly gentleman, will not speak like a teenager, for example. Therefore, the school must learn how to work with this language so as not to fall into the trap of not being able to teach the cultured norm and to strengthen the prejudice against the other varieties.

In this sense, Bechara (1985, p.9) questions the teaching of grammar and warns us that great care must be taken when trying to get out of the traditionalism of normative grammar and entering the "new wave". The author discusses the teaching of formal language and informal language, clarifying that the teaching of one of two ways, alone, would take away from the individual the opportunity to choose which variant to use. The grammarian says that the role of the Portuguese teacher is to make the student a polyglot within the language itself. Developing your ability to use the language in a different way in different contexts, according to the current needs. For the individual, upon arriving at school, already knows the Portuguese language, but his knowledge is limited to orality. Thus, what the teacher needs is to broaden the field of mastery that the learner already possesses regarding the language, leading to the enrichment of his oral expression and improving his ability to express his ideas, his emotions, his feelings, oral or written form, thereby broadening their language potential.

Still for Bechara, the teacher should not develop these skills privileging only the colloquial language; because it would fall into another reductionist extreme. He can not adopt the distorted view that language should be freed from any imposition and that, consequently, the "oppressed" should not accept a language other than their own as a form of reaction to the ruling class, forgetting, thus, from the cultured written tradition and not giving importance to the recommendations for the use of standard written code.

Thus, if we can consider an oppression the privilege given to the cultured language, it is also possible to consider oppression as the teaching of only colloquial language, since, in one way or another, only a possibility is being shown and thus depriving the individual of the Freedom of choice. Bechara (1985) says that The norms of the socalled "oppressor" and "dominant" class will be neither better nor worse, or the norms of the literary language will be neither better nor worse than those used in the colloquial language. As Professor Rafaelle Simone rightly points out, "while the populist position perpetuates the linguistic segregation of the subaltern classes, language education should help their liberation."The populist thesis from the democratic point of view is as flawed as the thesis that it fights, since both insist on an old error of the old linguistic education, since both are of monolingual nature, that is, they only favor a variety of verbal code, or the so-called "cultured" mode (of the so-called "dominant" or "oppressive" class) or the colloquial modality (or the so-called "oppressed" class) (Bechara, 1985, p. 12)

In this sense, the teacher who works only with a linguistic variant, whether cultured or colloquial, fails because the task of linguistic education consists in having the student "control the various functions of language in the use of expressive resources" (Bechara 1985, p.13) and, for this, it is not necessary that work with the cultured norm excludes the colloquial or vice versa. On the contrary, one variety complements the other, illustrating what language is in a real context, not an ideal one. 


\section{Educational Sociolinguistics}

Currently, many explanatory possibilities for school failure are discussed. Let us focus on the lack of success in developing the language skills of the individual. In this paper, we present the results of the study by Bagno, Gagné, Stubbs (2002), Gnerre (2003), Bagno (2001, 2004, 2007a, 2007b), Scherre (2005), Neves (2003, 2005), Perini 2005) Antunes (2007, 2009, 2012), Travaglia (2009), among others, we can affirm that the school considered as main instrument for the teaching of Portuguese language normative grammar.This is in a conception of a homogeneous language, in which, according to Bagno (2007a), language is a particular set of rules, a model of good talk, a product of artificial social convention, which does not correspond to what language is, in fact, . "Language, in the conception of sociolinguists, is intrinsically heterogeneous, multiple, variable, unstable and always in deconstruction and reconstruction" (Bagno, 2007a, 36). Language is, fundamentally, a social activity. It is spoken by human beings who are heterogeneous and are always in transformation. In this sense, for the author, there is a branch of linguistics whose primary task is to relate the heterogeneity of language to social heterogeneity: sociolinguistics.

With the recognition that language is heterogeneous, as well as social individuals - who use it - linguistic variation becomes the axis of sociolinguistics. According to Mollica (2008, p. 9), "Sociolinguistics is one of the sub-areas of Linguistics and studies the language in use within the communities of speech, turning to a type of research that correlates linguistic and social aspects" is an interdisciplinary science in the fine line between language and society.

Bortoni-Ricardo was one of the first researchers to combine the postulates of sociolinguistics with questions related to the teaching of mother language in Brazil. According to Bortoni-Ricardo (2009), Sociolinguística in its different aspects - namely, qualitative and variationist - has shown concern about school performance and has contributed significantly to research related to educational issues. Always seeking to renew, to improve methodologies to assist the teacher in his pedagogical practice, aiming at the best performance of the students. The researcher discusses grammatical topics (phonological, phonological, morphosyntactic, semantic and pragmatic-cultural) in different varieties and contexts of use, both oral and written, observing the functional principles of language use. the theoretical and methodological apparatus of sociolinguistics can help in the teaching of the mother language (Bortononi-Ricardo, 2004, 2005, 2006) and Bortoni-Ricardo and Freitas (2009), Bortoni-Ricardo, Machado and Castanheiro, (2010); Bortoni-Ricardo et al, (2014).

If, in our daily lives, we have various social situations ranging from the more informal (such as a chat with friends) to the more formal one (such as a conference), consequently we will have changes in the way we speak, as the sociocommunicative situation. In this way, there are degrees of monitoring in the use of language: in a more informal situation, the degree of monitoring is lower; in a more formal situation, a greater degree of monitoring in the use of language is required (Bagno, 2007a).

\section{Language teaching in the initial years of elementary school: pedagogical practice}

In order to observe how Portuguese language teaching is occurring in the initial years of elementary school, we observed classes at a school that attends this school stage, in Luziânia, Goias. For that, we had as base the postulates of the interpretative paradigm, one of the slopes of the social sciences. In this sense, we adopted the qualitative research methodology. According to this paradigm, to observe the world, it is necessary to observe the social practices and the meanings in force, so the qualitative research seeks to interpret social phenomena in a given context (Bortoni-Ricardo, 2008). Observations of classes were carried out in 3 classes, being a class of $3^{\circ}$ year, one of $4^{\circ}$ and another of $5^{\circ}$ year. We chose these classes because we consider that the students are already at a more advanced stage of the literacy and literacy process. Four classes were observed in each class.

During the classes observed, we noticed the teachers' concern about working with the textual genres. According to Marcuschi (2008) it is a consensus among linguists that one should teach the language through texts. The author proposes questions that can be worked using texts:

a) The questions of the historical development of the language;

b) The language in its authentic and not simulated functioning;

c) The relations between the different linguistic variants;

d) The relations between speech and writing in the actual use of the language;

e) The phonological organization of the language;

f) Morphological problems at their various levels; 
g) The operation and definition of grammatical categories;

h) The patterns and organization of syntactic structures;

i) The organization of vocabulary and vocabulary;

j) The functioning of semantic language processes;

k) The organization of intentions and pragmatic processes;

1) Writing strategies and style issues;

m) Thematic progression and topical organization;

n) The training of reasoning and argumentation;

o) The study of textual genres;

p) The training of the magnification, reduction and summary of text;

q) The study of punctuation and spelling;

r) The residual problems of literacy.

(Marcushci, 2008, p.51-52)

However, our research has shown that the question is not what to work but how to work Portuguese in the classroom. During the classes observed, in general, we noticed the emphasis on teaching based on normative grammar, without considering social aspects of language use, despite the concern with textual genres. To illustrate, let us see a class of teacher A (5th year), in which she set out to work on a poem:

Field note 1

The teacher began by asking questions about the poem "A different school": what is the author's name? What is the textual genre? Subsequently, five questions were raised in the table:

1) What is the main theme of the poem?

2) What subjects did students learn?

3) Why was this a different school?

4) Circle the nouns themselves and write them below:

5) Pass the words below that are in the plural to the singular and then rank each in oxytone, paroxitone and proparoxytone:

a) Reptiles

b) Common

c) Mammals

d) Birds

e) Bicycles

The teacher emphasized questions 4 and 5, explaining the concepts to the students so that they could carry out the exercise. The students, who finished, took the notebook to the teacher so that she could give the visa. Some students showed difficulties, asked questions about mistakes or correct answers, and the teacher responded. To finish the lesson, the teacher corrected the activities, asked and the class responded. Therefore, the correct answers were placed on the board. In this sense, we wonder if, in this way, the text would not be used as a pretext to teach grammar.

In a fourth grade class, teacher B proposed to the class to work with the cordel. He explained that it was a poetic genre that emerged in northeastern Brazil in the late nineteenth century. As the students asked what "XIX" meant, the lesson consisted in teaching the Roman numerals:

Field note 2

"The teacher spent a good part of the class helping the children to remember the Roman numerals. And the cords became homework".

Such an episode leads us to question about the teacher's real goals in order to think about what is his focus, what he prioritizes in the classroom. Why would he change all planning based on the study of a genre as a cordel to explain Roman numerals? What conception of language and teaching do we have underlying the teacher's decision-making?

It turns out that, in fact, the consensus on working the language from texts has reached the classrooms. Nevertheless, if we look at the issues listed by Marcuschi (2008) to be worked on based on texts, we believe that how to work from texts in pedagogical practice still needs to be improved. 


\section{Final Considerations}

Observing the conception of language from a normative grammar perspective, as opposed to a sociolinguistic perspective, one can see that, in the normative perspective, the degrees of monitoring of language use according to sociocommunicative situations are not considered.

Considering our observations of pedagogical practice in Portuguese language teaching in the initial years of elementary school, we can arrive at the following conclusions: the relation between theory and practice in the teaching of Portuguese in the initial years of elementary education needs to be considered with more emphasis, so that the objectives of the teacher with certain activities become clearer for him and for the students; in the pedagogical practice of teachers, the conception of language as a code is evident, since the focus is classificatory activities and there is no consideration of different sociocommunication situations for the use of the language. Thus, there is the assumption that there is only one way of using the language: that prescribed by the standard norm. In this sense, that variant that the child brings home - which will probably have low degree of monitoring, since the family environment and the conviviality with the friends allow it, and that children do not usually participate in many formal situations of communication - will be considered "wrong", "misrepresented" and, consequently, ignored in school in favor of the standard norm. According to Teixeira (2010), in this perspective based on the conception of homogeneous language and, consequently, under the imperative of right and wrong, the conception of language teaching becomes very simplistic in view of the communicational reality, as can be observed in the works of authors whose theoretical approach to language description is constituted based on functional principles (Perini, 2006 and 2010; Bagno, 2011).

Based on Ausubel's theory of meaningful learning, in which the pillar of learning is the knowledge the student already possesses (Martín and Solé, 2004), the lack of consideration of the individual's prior knowledge of the language - often with a low degree of and that it has rules of operation different from those placed by the standard norm - so that it can build knowledge, can make it difficult to understand the functioning of the language, in its cultured norm, by the child. It is as if we are trying to build a house from the ceiling (what the student wants to know), not the base (what the student knows). Ausubel called this anchoring mediation in the subsumption concepts.

Still from the perspective of the homogeneous language, with a Portugueselanguage teaching that privileges only a possibility of using the language, the standard norm, there is a risk of not developing the student's linguistic abilities, it is understood as a linguistic ability to know how to monitor the use of the language, and have the resources to do so, in any socio-communicative situation, from the most formal to the most informal. Thus, the change of language conception becomes essential for the change in the pedagogical practice of Portuguese languageteaching.

\section{References}

Almeida, M. J. (1984)Ensinar Português In Geraldi, J. W. (org).O texto na sala de aula. São Paulo: Ática, (Chapter $6)$.

Antunes, I. (2012)O território das palavras:estudo do léxico em sala de aula. São Paulo: Parábola Editorial. (2009)Língua, texto e ensino: outra escola possível. São Paulo: Parábola Editorial.

(2007) Muito além da gramática: por um ensino de língua sem pedras no caminho. São Paulo: Parábola Editorial.

Bagno, M.; Gagne, G.; Stubs, M.(2002) Língua materna: letramento, variação e ensino. São Paulo: Parábola, 2002.

Bagno, M.(2011) Gramática pedagógica do Português Brasileiro. São Paulo: Parábola Editorial.

. (2007a) Nada na língua é por acaso: por uma pedagogia da variação linguística.São Paulo: Parábola Editorial. (2007b) O Preconceito Linguístico: o que é, como se faz. São Paulo: Edições Loyola. . (2004) Português ou Brasileiro?: um convite à pesquisa. São Paulo: Parábola Editorial. (2011)Dramática da Língua Portuguesa:Tradição Gramatical, Mídia e Exclusão Social. São Paulo: Loyola.

Bauer, M.W.(2002) Análise de conteúdo clássica: uma revisão. In: Bauer, M.W.; Gaskell, G. (Eds.) Pesquisa qualitativa com texto: imagem e som: um manual prático. Petrópolis, RJ: Vozes.

Bechara, E.(1985) Ensino da Gramática:Opressão? Liberdade?. São Paulo: Ática, 1985. 
Bortoni-Ricardo, S.M. et al (Orgs) (2014)Por que a escola não ensina gramática assim?. São Paulo: Parábola Editorial.

Bortoni-Ricardo, S.M; Machado, V.R.; Castanheira, S.F.(2010)Formação do professor como agente letrador. São Paulo: Contexto.

Bortoni-Ricardo, S.M.; Freitas, V.A.F. (2009) Sociolinguística Educacional. In: HORA, D. et al (Orgs). Abralin 40 anos em cena. João Pessoa: Editora Universitária. pp. 217-241.

Bortoni-Ricardo, S.M.(2008)O professor pesquisador: introdução à pesquisa qualitativa. São Paulo: Parábola Editorial. (2006) Métodos de Alfabetização e consciência fonológica: o tratamento de regras de variação e mudança. Scripta: Belo Horizonte - PUC Minas, v. 9, n. 18, p.201-220. (2005) Nós cheguemu na escola, e agora? Sociolinguística e educação. São Paulo: Parábola Editorial, 2005. (2004) Educação em língua materna: a sociolinguística na sala de aula. São Paulo: Parábola Editorial.

Gibbs, G.R. (2007)Analysing qualitative data. London: Sage publication..

Gnerre ,M. (2003)Linguagem, escrita e poder. São Paulo: Martins Fontes.

Lobato, L.M.P. (1986) Sintaxe Gerativa do Português: da teoria padrão à teoria da regência e ligação.Belo Horizonte: Vigília.

Marcushi, L. A. (2008)Produção textual, análise de gêneros e compreensão. São Paulo: Parábola Editorial.

Martin, E.; Sole, I.(2004) A aprendizagem significativa e a teoria da assimilação. In: Coll, C.; Marchesi, A.; Palacios, J. (Orgs). Desenvolvimento psicológico e educação. Porto Alegre: Artmed.

Mollica C.(2008) Fundamentação teórica: conceituação e delimitação. In: Mollica, C.; Braga, M.L. (Orgs). Introdução à sociolinguística: o tratamento da variação. São Paulo: Contexto.

Neves, M. H. M.(2005)Gramática na escola. São Paulo: Contexto, 2005. (2003) Que Gramática estudar na escola?:norma e uso na língua portuguesa. São Paulo: Contexto.

Perini, M.A. (2010)Gramática do português brasileiro. São Paulo: Parábola Editorial, 2010. . (2006) Gramática descritiva do português. São Paulo: Editora Ática. (2005) Sofrendo a gramática. São Paulo: Editora Ática.

Possenti, S. (1984)Gramática e Política In GERALDI, João W. (org).O texto na sala de aula. São Paulo: Ática.

Scherre, M.M.P. (2005)Doa-se lindos filhotes de poodle: variação linguística, mídia e preconceito. São Paulo: Parábola Editorial. .

Silva, M. C. P. S. \& Koch, I. G. V. (2003)Linguística aplicada ao português: morfologia. São Paulo: Cortez.

Teixeira, Z.D. (2010)Advérbios: uma análise semântica e suas implicações para o ensino de língua portuguesa. Curitiba: Editora CRV.

Travaglia, L. C. (2009)Gramática e Interação: uma proposta para o ensino de gramática nos primeiro e segundo graus.São Paulo: Cortez. 